\title{
THE IMPACT OF E-COMMERCE DEVELOPMENT ON THE WAREHOUSE SPACE MARKET IN POLAND
}

\author{
Izabela Dembińska \\ University of Szczecin, Faculty of the Management and Economic of the Services, Department of Logistics, \\ Poland, izabela.dembinska@wzieu.pl
}

\begin{abstract}
The subject of discussion in the article is the impact of e-commerce sector on the warehouse space market. On the basis of available reports, the development of e-commerce has been characterized in Poland, showing the dynamics and the type of change. The needs of e-commerce sector in the field of logistics, in particular in the area of storage, have been presented in the paper. These needs have been characterized and at the same time, how representatives of the warehouse space market are prepared to support companies in the ecommerce sector is also discussed. The considerations are illustrated by the changes that occur as a result of the development of e-commerce on the warehouse space market in Poland.
\end{abstract}

Keywords: e-commerce, warehouse, warehouse spaces market

Type of the paper: Empirical study

JEL Classification: H54, L19, L81

\section{Introduction}

The development of e-commerce is associated with the development of the logistics sector. This presents a need for new types of logistics services. The new forms of service offered by logistics companies require a properly prepared logistics infrastructure.

According to forecasts for 2016, a strong demand for warehouse space and logistics company will be generated by the e-commerce sector and automotive industries, as well as retailers and logistics operators ("Logistyka e-commerce" 2015). In the light of the development of e-commerce, as observed in recent years in Poland, the question must be asked whether the supply of warehouse space is growing enough to meet the needs of e-commerce. It is not just about the amount of available storage space. The attributes of quality of warehouse facilities are also important. Accepting the thesis that the development of e-commerce sector largely affects the quantitative and qualitative changes occurring in the market warehouse, the aim of this article is to present these changes in terms of theoretical and empirical, referring to the example of Poland. You may have noticed that the demand for warehouse space in Poland (as in other European countries) is generated primarily by e-commerce companies (e.g. Amazon). It is also worth noting that the storage facilities are changing to better fulfil the functions associated with the operation of e-commerce.

This is a review article. The impact of e-commerce on the transformation taking place on the warehouse market is still not well described in the literature, as sources are primarily reports, specialist studies, or available expertise. The data, which confirm the existence of this influence, and thus showing the changes emanate from research carried out by companies that had long been periodically examining the warehouse market, that is, Colliers, Jones Lang LaSalle IP (JLL), and Cushman \& Wakefield.

\section{Development of the e-commerce in Poland}

Europe has a population of 880 million people, out of which 564 million people use the Internet and 331 million people are e-shoppers. The share of e-commerce in the European GDP was $2.45 \%$ in 
2014. The UK, Germany and France together account for about $60 \%$ of the European e-commerce market (Fig. 1) (“European B2C" 2015).

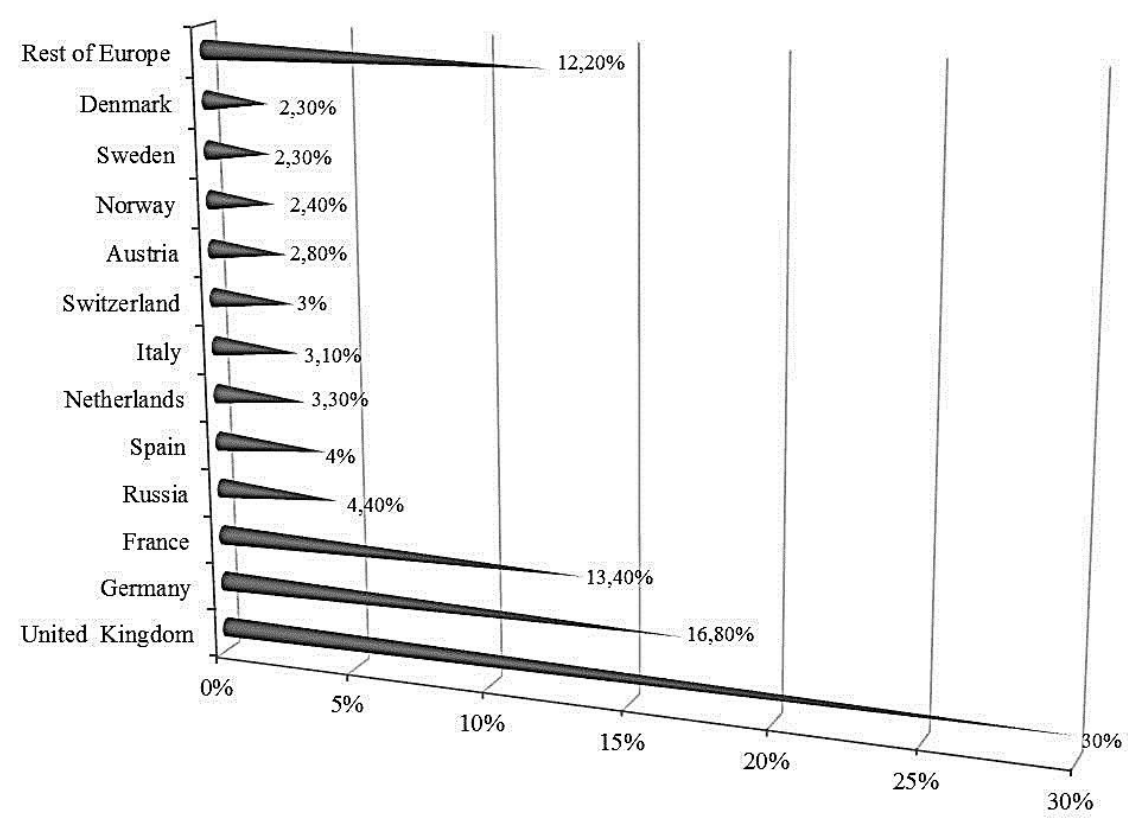

Fig. 1. Share of European B2C e-commerce market, 2014 (Source: "European B2C E-commerce", Report 2015)

Over recent years, there has been a dynamic development of e-commerce market in Poland. This is associated with the general trend of development of e-commerce, which is observed in the world. The contributing factor to this growth is especially improvement of information technology and communications (ICT) and the increasing prevalence of the Internet. This is determined by, relative to the traditional trade, lower operating costs, greater impact, and greater flexibility to offer as well (Chiang, Dholakia 2003; Rodríguez-Ardura et al. 2008; Kabango, Asa 2015). Besides, more and more companies assume that the activity on the network is a must in present times. For some businesses (trade activities), the e-commerce route serves a supporting role in relation to traditional trade by way of an "omnichannel"; for others, it is the sole channel of distribution and sales of their products.

Poland is considered to be the fastest growing e-commerce market in Europe (Fig. 2). While in 2006 in the Polish market operated only 2,800 online stores but, in 2008, there were already 4,500 and in 2010 more than half of the more, because approximately 10000 ("W syntetycznym" 2015). It is estimated that in 2015, the number of online shops in Poland could exceed 22,000 ("e-commerce," 2015). It is expected that the share of e-commerce in total retail sales in Poland in 2020 will be $10 \%$ and will be 2.5 times higher than in 2014 ("Logistyka e-commerce" 2015).

Polish e-commerce is very fragmented. As much as $85 \%$ of e-shops are micro and small enterprises. For traditional shops, Internet is often a source of additional sales. Only part of the companies focuses exclusively on e-commerce. About $50 \%$ of the entities in Poland receive an average of less than 100 orders a month, and only $7.8 \%$ have more than 1,000 orders per month (Kawa 2014).

More and more Poles are convinced of the advantages of e-commerce. According to Dotcom River, this form of trade already uses 32\% of Poles ("Logistyka e-commerce" 2015). Even if the data included is in such a way that the e-commerce uses every third Pole, in comparison with Western countries, it is still not much. For example, in 2013, 43.3 million Germans used online shopping ("Ecommerce w Polsce" 2014). At the same time, in the last few years, the level of spending in the Polish Internet is growing at a double-digit rate, and in 2014, it reached 3.9\% of the total retail sales in the country. Most often clothes, shoes, books, electronics and cosmetics are bought online. Interestingly, the limited range of traditional shops in towns with a population of less than 20,000 makes online shopping more popular in these towns ("Logistyka e-commerce" 2015). 


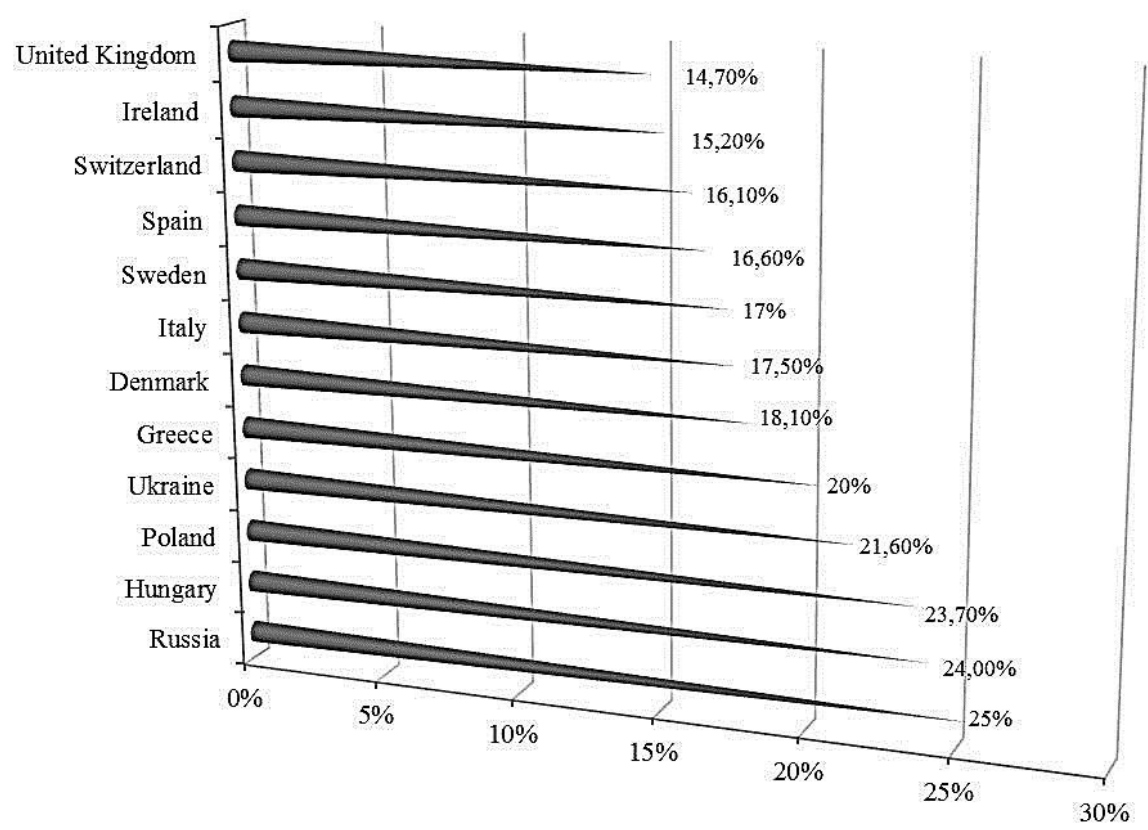

Fig. 2. Top 12 countries in terms of B2C e-commerce growth rate, 2014 (Source: "European B2C Ecommerce", Report 2015).

The development of e-commerce in Poland affects the geography of buying. More than half of Polish Internet users (54\%) buy products or services from Polish websites. Foreign online stores is currently used by $13 \%$ of the Poles and their share is still growing. The increase is due to the fact that on the one hand, more and more foreign shops have become destinations of supply in Central and Eastern European countries, including Poland. On the other hand, the Polish customers are becoming more trust in the foreign shops, therefore they are buying boldly at these stores. Besides, foreign online stores, through various forms of advertising, in a greater extent and more effectively reach the Polish customer.

Polish e-commerce is a promising and dynamically growing market. It is expected that the market value of e-commerce in Poland approaches in 2016 to 36 billion zloty and in the next five years is expected to double as well. The number of e-stores in 2016 will increase by $7 \%$ and will exceed the level of 23,500, and more than 30,000 in 2020 (Bellon 2016).

\section{Methodology}

The problem of characterizing the correlation between the development of e-commerce and warehouse space market in the literature, both Polish and foreign, is noticed; however, it is not well described. It is more practical than theoretical and may, therefore, be the subject of various studies in the form of reports, expert opinions, case study, not a scientific consideration, especially referring to specific economic theory and management theory. This does not mean that it does not deserve attention, taking consideration of this nature. Quite the contrary, regardless of the issue that will be placed at a higher emphasis, or on e-commerce, or on the warehouse space market, it is an interesting and important issue worthy of developing theoretical studies.

The aim of the discussion is to determine the impact of the development of e-commerce on the changes occurring in the warehouse market in Poland. Changes of a qualitative nature will be analysed. The subject of analysis of such changes in the warehouse space market is the impact of the needs and preferences of the entities on the demand side of e-commerce on the scope and standards of offered storage services. The source of the data forming the practical plane for considerations is reports characterizing the warehouse market in Poland. Reference will be data for 2013-2015. 


\section{Results}

Online shopping is increasingly attracting a huge number of customers due to their advantages. The main advantages of shopping on the Internet can include comfort of shopping (open 7/24), wide selection range, and speed of carrying out the order. For the customer, it is important to have lower price compared with the traditional trade. An important factor is the ease of returns and complaints. Goods that are ordered online are $22 \%$ more likely to be returned, compared to the $10 \%$ of goods that are bought offline (Brundage 2015). It should be noted that the benefits that e-commerce offers to customers largely depend on the potential of the logistics, understood as processes of storage, transportation, inventory availability, and management of logistics processes. These relationships are shown in Fig. 3.

The advantages of e-commerce

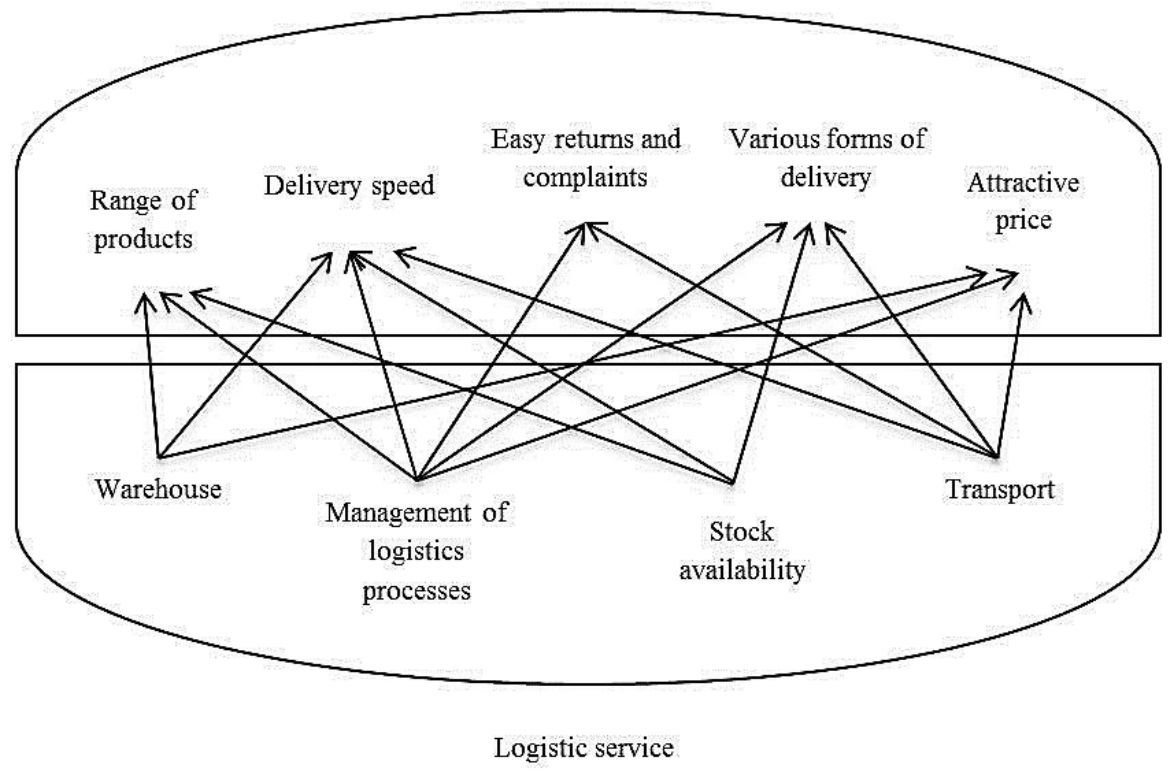

Fig. 3. Relations between the advantages of e-commerce and logistics potential (Source: author's compilation).

The role of logistics in the functioning of e-commerce can be seen in three basic areas: (1) transport of goods to the customer, (2) storage, and (3) goods management (forecasting supply, the flow of information, etc.).

The dynamic development of e-commerce observed in recent years in a natural way forced the logistics companies to expand their offer of support for this sales channel. It successively developed a different form of organization of logistics for e-commerce (Fig. 4). Among micro and small enterprises that dominate the logistics space, only transport is carried out on the basis of outsourcing. This form of organization of the logistics associated with the threat to the maintenance of high standards of customer service is in the event of a significant increase in sales. It prolonged delivery time and increases the risk of failure to timely delivery. Large companies, however, depending on the needs can only use transport or just storage, transport and storage, or the logistics services offered on the basis of one-stop e-commerce, although it is not yet a common practice of employing specialized logistics companies that provide a comprehensive range of logistics, including, in addition to transportation and storage solutions, accounting, marketing, etc. 


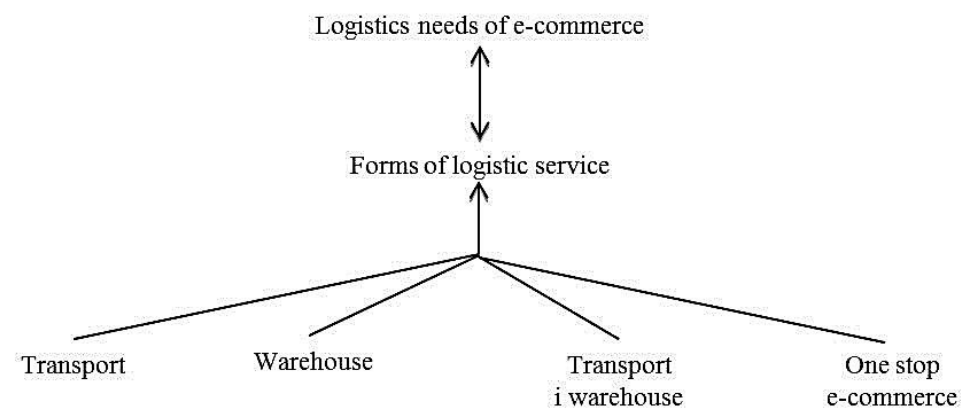

Fig. 4. Forms of logistics service of e-commerce (Source: author's compilation).

From the point of view of the management of logistics processes, it is important to identify the differences between the distribution of traditional methods for fixed stores and distribution in ecommerce. The main difference is identifying the recipient. There is a change of the system from B2B to $\mathrm{B} 2 \mathrm{C}$, and if the client is the recipient of the goods that point of receipt of the consignment may be different, due to the current customer preference. It can be a private house, but it could easily be pack station, a post office, a specific collection point. Satisfying that condition is determined by the organization of logistics. In addition, delivery, organized within the framework of e-commerce, must be quick and immediate. In the case of stationary shops, deliveries are planned and held according to the adopted schedule and therefore usually there is no time pressure. It is important to maintain the timeliness of delivery. An important issue is the difficulty in estimating demand, as well as the seasonality of sales in e-commerce. Both of these problems necessitate high flexibility in providing of free storage space.

The diversity of entities operating in the sector of e-commerce, and thus the diversity of needs and logistics operations carried out by them, affects the size of storage resources available to them (the size $\mathrm{m}^{2}$ of space or $\mathrm{m}^{3}$ cubic volume of storage). But it also brings in organizational and functional changes, which is attributed to storage facilities in supply chains dedicated to e-commerce sector. Observations of the warehouse space markets in countries such as Germany, the United Kingdom and the United States allow you to point out the following types of storage facilities dedicated to ecommerce (Fig. 5): (1) mega e-fulfillment centres, (2) parcel hub/sortation centre, (3) parcel delivery centre and urban logistics depot, (4) return processing centres, and (5) dot.com warehouse for online food fulfillment. The characteristics of these types of objects are shown in Table 1.

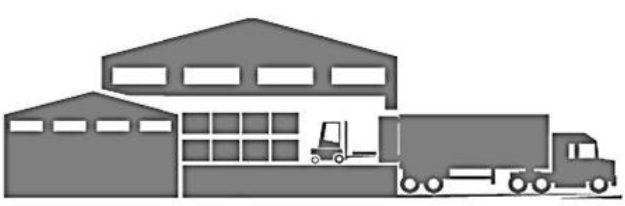

Mega e-fulfillment centers

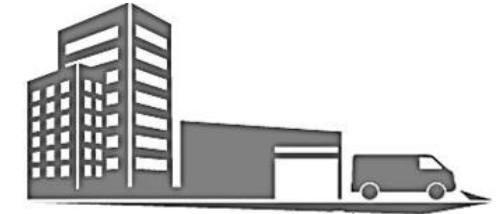

Parcel delivery center and urban logistics depot

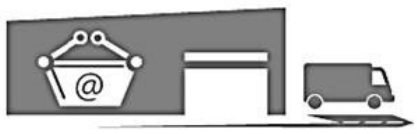

Dot.com warehouses for online food fulfillment

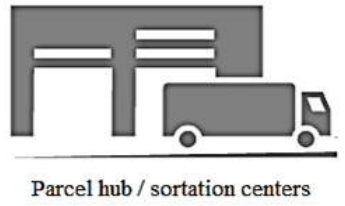

Parcel hub / sortation centers

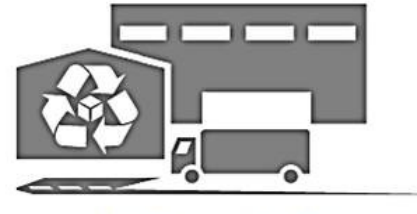

Return processing centers

Fig. 5. Types of warehouses depending on the functions for e-commerce sector

(Source: Logistyka e-commerce, 2015). 
Table 1. Characteristics of warehouse for e-commerce (Source: "E-commerce boom” 2013).

\begin{tabular}{|c|c|c|}
\hline $\begin{array}{c}\text { Type of e-commerce's } \\
\text { warehouses }\end{array}$ & Main building attributes & $\begin{array}{l}\text { Main location } \\
\text { attributes }\end{array}$ \\
\hline $\begin{array}{l}\text { Mega e-fulfillment } \\
\text { centers }\end{array}$ & $\begin{array}{l}\text { - Very large }-500,000 \text { sq } \mathrm{ft} \text { to } 1 \mathrm{mln} \text { sq } \mathrm{ft}+ \\
\text { - High bay }(15 \mathrm{~m}) \text { to accommodate mezzanine floors; } \\
\text { - Often cross-dock configuration; } \\
\text { - High level of employee parking to accommodate } \\
\text { full-time and seasonal staff. }\end{array}$ & $\begin{array}{ll}\text { - } & \text { Close to parcel hub } \\
\text { - } & \text { Close to large labour } \\
& \text { supply } \\
\text { - } & \text { Does not need a } \\
\text { traditional centre of } \\
\text { gravity location. }\end{array}$ \\
\hline $\begin{array}{l}\text { Parcel hub/sortation } \\
\text { center }\end{array}$ & $\begin{array}{l}\text { - High length to width ratio; } \\
\text { - Low site density; } \\
\text { - Cross-dock configuration with extensive loading } \\
\text { for lorries; } \\
\text { - } 360 \text {-degree circulation around the building; } \\
\text { - Highly automated internal operation involving } \\
\text { sortation systems. }\end{array}$ & $\begin{array}{l}\text { Centre of gravity } \\
\text { location to feed local } \\
\text { parcel delivery centres } \\
\text { in hub and spoke } \\
\text { network. }\end{array}$ \\
\hline $\begin{array}{l}\text { Parcel delivery center } \\
\text { and urban logistics } \\
\text { depot }\end{array}$ & $\begin{array}{l}\text { - High length to width ratio; } \\
\text { - Low site density; } \\
\text { - Cross-dock configuration with extensive loading } \\
\text { for vans; } \\
\text { - } 360 \text {-degree circulation around the building. }\end{array}$ & $\begin{array}{l}\text { Edge of major cities and } \\
\text { urban areas for home } \\
\text { delivery or delivery to } \\
\text { collection points. }\end{array}$ \\
\hline $\begin{array}{l}\text { Return processing } \\
\text { centers }\end{array}$ & Typically bespoke, depending on operation & $\begin{array}{l}\text { Located to return items } \\
\text { to e-fulfillment centres }\end{array}$ \\
\hline $\begin{array}{l}\text { Dot.com warehouse for } \\
\text { online food fulfillment }\end{array}$ & $\begin{array}{l}\text { - Specification reflects type of operation } \\
\text { - Bespoke loading provision for vans } \\
\text { - Extensive yard area for trailer and van parking and } \\
\text { ample parking for high number of staff. }\end{array}$ & $\begin{array}{l}\text { Edge of major cities and } \\
\text { urban areas where } \\
\text { online food order } \\
\text { volumes are highest. }\end{array}$ \\
\hline
\end{tabular}

The requirements of the e-commerce sector to logistics companies, especially to developers of warehouse space, are becoming larger. These requirements apply to storage facilities, which are primarily technical specifications. Technical specification is dictated by the type of operation, which are to take place in them. Companies from the e-commerce sector are looking for the following features storage facilities ("Logistyka e-commerce" 2015):

(a) More docks in the facilities of cross-dock: The standard rate of docks stands at 1 dock / 1000 $\mathrm{m}^{2}$, on the premises dedicated to e-commerce sector. This ratio increasingly is 1 dock $/ 500 \mathrm{~m}^{2}$, which is related to the rate service of handling work and more serviced cars;

(b) More power (dual power source), more efficient HVAC systems: With an increase in employment, the effectiveness of systems should be optimized, not in relation to the type of goods, but the number of employees.

(c) Entresols: Buildings dedicated to e-commerce companies should take into account the additional space located on the mezzanine, which could be used for additional shelves or zones of picking, packing, returns handling or other activities.

(d) Larger parking for staff: Service orders online is labor-intensive process, which involves the employment of more staff than in standard warehouses, and therefore the objects intended to support e-commerce companies should be equipped with a sufficient number of employee parking spaces.

Developers of warehouse operating in Poland are familiar with the needs of the e-commerce sector. Their idea of the most important features of the warehouse dedicated to e-commerce coincides with the needs reported by this sector, which is reflected in the study made by JLL \& Prologis in October 2015. According to the logistic operators, the most important features of warehouses designed for ecommerce are ("Logistyka e-commerce" 2015): 
a) the flexibility to increase or decrease the leased area - as indicated by $70 \%$ respondents who are logistics operators,

b) warehouse entresols - as indicated by $50 \%$ of logistics operators,

c) a high level of security and additional social areas - as indicated $40 \%$ of logistics operators,

d) more power, equipped with automatic and intensive HVAC systems - as indicated by $40 \%$ of respondents,

e) have a large parking for employees - as indicated by $40 \%$ of respondents,

f) the high ratio of surface area to the docks - that shows $30 \%$ of logistics operators,

g) above the standard height of the light - as indicated by $20 \%$ of the respondents.

The e-commerce sector reports to the developers of warehouse space needs not only on technical or organizational and functional attributes of storage facilities. The location of free storage space is also very important to them. This is because it determines the strategies of logistics systems and customer service of e-commerce businesses.

E-commerce is one of the fastest growing sectors of the Polish economy. Although the share of online sales in retail sales in Poland is not as large as in other EU countries, the share of e-commerce in the demand for storage is relatively high (Fig. 6).

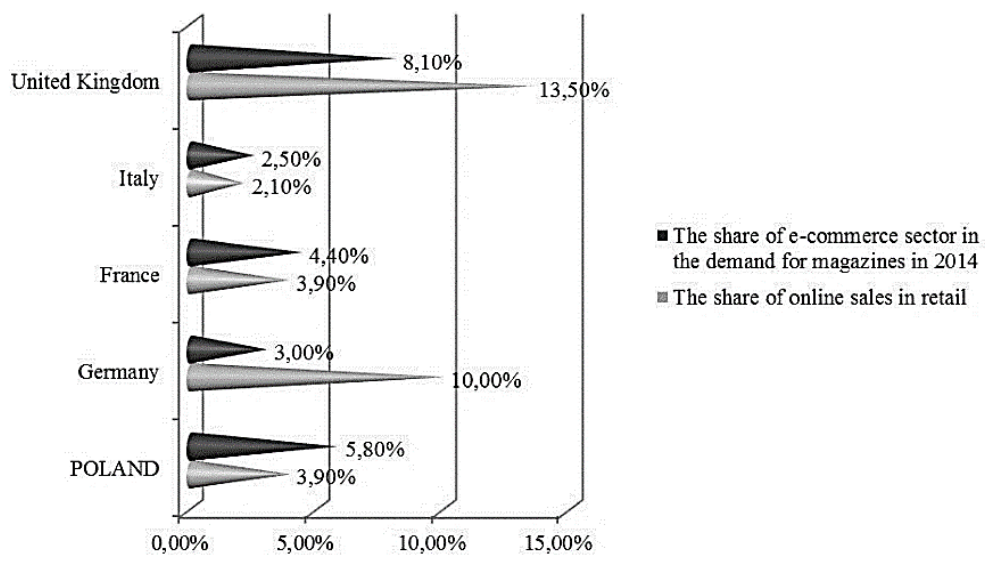

Fig. 6. The share of e-commerce in retail sales and demand for warehouses (Source: author's compilation based on "Logistyka e-commerce" 2015).

The supply of modern warehouses reached in 2015 in Poland, occupying nearly 10 million $\mathrm{m}^{2}$. The net demand reached 1.47 million $\mathrm{m}^{2}$ and a contract was additionally signed, extending for an additional 0.75 million $\mathrm{m}^{2}$ of warehouse space ("Rynek nieruchomości" 2016). In 2013 began, so far, the biggest investment in the e-commerce sector was the result of three large transactions including Amazon, with the two largest developers Panattoni and Goodman. The objectives have been put into use in 2014 . And they are:

- Amazon Poznań (Panattoni) with the area of 123,000 m²;

- Amazon Wrocław (Panattoni) with the area of 123,000 $\mathrm{m}^{2}$;

- Amazon Wrocław (Goodman) with the area of 123,000 $\mathrm{m}^{2}$.

These three centres are located in the Polish part of the European network of the Amazon, counting a total of 29 logistics centres (109 logistics centres all over the world). The location has been chosen so that they can serve the market of Western Europe. In terms of the technical facilities built for Amazon, they conform to warehouse facilities dedicated to the needs of e-commerce. In the logistics center in Sady near Poznań, the storage area is $91570 \mathrm{~m}^{2}$, while office and social area has been designed on two 
levels $-8972 \mathrm{~m}^{2}$. The object has 60 docks and has 2154 parking spaces for cars and 97 for trucks, 32 for the disabled, and 16 for motorcycles.

The share of renters of e-commerce in gross demand reached 5.8\% in 2014 in Poland. Assuming that the value of e-commerce in Poland will grow at a rate of $15 \%$ per year, it can be assumed that by 2020 the companies of e-commerce sector can rent up to $700,000 \mathrm{~m}^{2}$ of warehouse space. This means that ecommerce will become the main driver of growth in demand for warehouse space over the coming years.

Poland is a very attractive location for foreign companies in the e-commerce sector, mainly due to lower rent charges for warehouse space, as well as due to lower labor costs than in Western European countries. For this reason, it is expected that these companies will move their logistics centres from Western Europe, thereby initiating its operations in Poland. In the circle of interest will be locations such as Wrocław and Poznań, mainly due to transport costs. The location near the border, and Wroclaw and Poznan meet this condition. It gives the opportunity for the functioning of efficient distribution of products in the German market. The area of the central Poland, like Łódź, Warszawa, Piotrków and Trybunalski will be very popular among e-commerce companies representing the domestic market. Also in this case the location of logistics centres will determine the cost of the transport of the service area.

Analysing the rent transaction signed in the last few years indicates the following types of transactions:

- Direct contracts from the Internet companies or traditional networks, which have invested in a magazine dedicated to the online channel;

- Agreements of logistics operators who are engaged in handling online orders at the request of the outsourcing;

- Omni-channel transactions, where only a part of the surface is designed to handle online orders.

Estimating the impact of e-commerce on the demand for warehouse space is not easy. It is closely connected with some difficulties. Many retail chains that carry out logistics services on their own usually dedicate part of the warehouse to handle online orders. An additional complication is the fact that the size of this share varies in time and is usually not made available. Another problem is that the logistics operators working for companies in the sector of e-commerce usually do not provide information on what part of their rented space is dedicated to those companies. In turn, the courier companies usually choose to operate in their own buildings, and are therefore not included in the statistics of rent commercial warehouse space.

\section{Conclusions}

The aim of the article was to show how the development of the e-commerce sector affects the warehouse space market. The considered problems indicate that the deliberations were not conducted against the background of the scientific methodology, but are cross-cutting, pointing to individual changes. The characteristic of these changes lead to the conclusions that can be presented in two groups: general conclusions and proposals for the Polish warehouse space market.

The main factor determining the growth of warehouse space will be the further dynamic development of the e-commerce sector.

E-commerce sector will specialize their needs in the use of storage, which will be associated with logistics strategies by which the e-commerce companies will operate. These needs, however, will lead to specialization of warehouses and their equipment.

The needs of e-commerce sector to the warehouse space market will be determined by the increase in the share of purchases by mobile ( $\mathrm{m}$-shopping - mobile shopping) and social networking (f-shopping - Facebook shopping). To develop these forms of purchase, you may need to deliver the same day 
(same day service), and the fulfillment of this condition depends on the availability of the goods, that is, from the network of warehouses.

The tenants of the e-commerce sector will be increasingly interested in the locations allowing efficient distribution of goods in cities Suburban distribution hubs will be created, but the tenants will direct their attention parallel to the existing urban logistics centres and facilities such as the small business units.

Poland is, and in the near future will continue to be, an attractive place for the location of warehouse space for the needs of e-commerce sector. Therefore, developers will invest, even on the basis of speculative investments, in facilities dedicated to e-commerce, which indicates that e-commerce will be the main driver of the market development of warehouse space in Poland.

It is expected that the division of attractive locations for foreign companies and those attractive for domestic companies will still continue. Foreign companies will choose Poznan and Wroclaw, while domestic companies will be located in central Poland. One can also assume that foreign companies will be locating in southern Poland with the intention of organizing the delivery of goods in the direction of Central and Eastern Europe.

\section{References}

Bellon, M. (2016). E-commerce w Polsce stale przyspiesza. [Accessed 15.02.2016]. Available: http://pulsinnowacji.pb.pl/4418019,7215,e-commerce-w-polsce-stale-przyspiesza

Brundage, T. (2015). Is Your Warehouse Ready for E-Commerce? [Accessed 20.01.2016]. Retrieved from http://speconthejob.com/is-your-warehouse-ready-for-e-commerce/

Chiang, K. P., \& Dholakia, R. R. (2003). Factors driving consumer intention to shop online: an empirical investigation. Journal of Consumer Psychology, 13(1-2), 177-183.

E-commerce boom triggers transformation in retail logistics. [Accessed 21.01.2016]. Retrieved from http://magazyny.pl/media/reports/Global_E-commerce_Reports.pdf

E-commerce w Polsce dopiero rozkwitnie. [Accessed 28.01.2016]. Retrieved from http://www.forbes.pl/ecommerce-w-polsce-dopiero-rozkwitnie, artykuly, $174351,1,1$. html

E-commerce: ile z $31 \mathrm{mld}$ zł dla polskich e-sklepów? [Accessed 20.01.2016]. Retrieved from http://fp20.org/ecommerce-ile-z-31-mld-zl-dla-polskich-e-sklepow, 1243

European B2C E-commerce, Report 2015. [Accessed 28.06.2016]. Retrieved from http:// www.ecommerceeurope.eu/.../european-b2c-e-commerce-report.

Kabango, Ch. M., \& Asa, A. R. (2015). Factors influencing e-commerce development: Implications for the developing countries. International Journal of Innovation and Economics Development, 1(1), 64 - 72.

Kawa, A. (2014). Logistyka e-handlu w Polsce. [Accessed 20.01.2016]. Available: https://media.pocztapolska.pl/file/.../logistyka_e_handlu_w_polsce.pdf

Logistyka e-commerce w Polsce. Przetarte szlaki dla rozwoju sektor. (2015). [Accessed 27.01.2016]. Retrieved from http://www.jll.pl/poland/pl-

pl/Research/Logistyka_e_commerce_w_Polsce_przetarte_szlaki_dla_rozwoju_sektora_raport.pdf

Rodríguez-Ardura, I., Meseguer-Artola, A., \& Vilaseca-Requena, J. (2008). Factors Influencing the Evolution of Electronic Commerce: An Empirical Analysis in a Developed Market Economy. Journal of Theoretical and Applied Electronic Commerce Research, 3(2), 18-29.

Rynek nieruchomości magazynowych w Polsce w 2015. (2016, February). [Accessed 20.02.2016]. Retrieved from http://magazyny.pl/blog/raporty/raporty-ogolnopolskie/raport-jll-2015-o-rynku-powierzchnimagazynowych-w-polsce/

W syntetycznym skrócie o rozwoju rynku e-commerce w Polsce. (2015, May 29). [Accessed 28.01.2016]. Retrieved from http://www.forbes.pl/rozwoj-rynku-e-commerce-w-polsce,artykuly,195234,1,1.html\# 